\title{
Transformation Behavior and Microstructures in Ultra-low Carbon Steels
}

\author{
Koji SHIBATA and Kentaro ASAKURA
}

Engineering Research Institute, The University of Tokyo, Yayoi, Bunkyo-ku, Tokyo, 113 Japan.

(Received on March 1, 1995; accepted in final form on May 26, 1995)

\begin{abstract}
$\mathrm{Fe}-0.002 \% \mathrm{C}, \mathrm{Fe}-0.01 \% \mathrm{C}, \mathrm{Fe}-1.5 \% \mathrm{Mn}-0.001 \% \mathrm{C}$ and $\mathrm{Fe}-1.5 \% \mathrm{Mn}-0.01 \% \mathrm{C}$ steels were vacuum-melted and examined. $\mathrm{Fe}-0.05 \% \mathrm{C}$ and $\mathrm{Fe}-1.5 \% \mathrm{Mn}-0.05 \% \mathrm{C}$ steels were also melted and used for comparison. The effects of cooling rate and chemical composition on microstructures were examined by optical and electron microscopy. Autoradiography of boron was also performed in order to know relation between $\gamma$ and $\alpha$ grain boundaries and effects of microstructures on discontinuous yielding were also examined. The fraction of quasi-polygonal ferrite $\left(\alpha_{q}\right)$ increases with the cooling rate and the contents of $\mathrm{C}$ and $\mathrm{Mn}$. Dislocation density in $\alpha_{q}$ is higher than that in polygonal ferrite $\left(\alpha_{p}\right)$ and dislocations tend to form cell structures in $\alpha_{q}$ matrix, whereas dislocations which do not form cell structures were also observed. Normal cooling rate dependence of ferrite grain size was not observed in $\mathrm{Fe}-0.002 \% \mathrm{C}$ and $\mathrm{Fe}-1.5 \% \mathrm{Mn}-0.001 \% \mathrm{C}$ steels. By autoradiography of boron it was known that not a small fraction of grain boundaries of ferrite might be coherent. Even in the ultra-low carbon steels cooled at $360^{\circ} \mathrm{C} / \mathrm{s}$, cementite was observed on ferrite grain boundaries. Discontinuous yielding was suppressed by bainite transformed during continuous cooling, while $\mathrm{Mn}$ enhanced discontinuous yielding. Bainite and martensite could be observed in the specimens of $\mathrm{Fe}-0.002 \% \mathrm{C}$ and $\mathrm{Fe}-1.5 \mathrm{Mn}-0.001 \mathrm{C}$ steels cooled at the rate higher than $360^{\circ} \mathrm{C} / \mathrm{s}$. In such specimens, the continuous change from $\alpha_{q}$ to bainite was observed. Martensite can be distinguished from bainite by its higher microhardness and thinner lath width.
\end{abstract}

KEY WORDS: ultra-low carbon steel; cooling rate; grain size; ferrite; bainite; martensite; cementite; microhardness; discontinuous yielding; auto-radiography; lath width.

\section{Introduction}

Details of transformation behavior and microstructures of ultra-low $(<0.02$ mass $\%$ ) carbon steels have remained unclarified. For instance, Araki et al. ${ }^{1)}$ named ferrite having curved grain boundaries as quasi-polygonal ferrite $\left(\alpha_{q}\right)$ and they have thought that such $\alpha_{q}$ may include massive ferrite. But interrelation between $\alpha_{q}$ and massive ferrite has not been elucidated. Shibata et al. $^{2)}$ observed fine precipitates of cementite on the ferrite grain boundaries of $\mathrm{Fe}-0.002 \% \mathrm{C}$ steel quenched from austenite region. Generally speaking, it is difficult to conceive that carbide precipitates from austenite or ferrite during quenching such ultra-low carbon steels. Hence much more observation of the carbide precipitation should be performed in ultra-low carbon steels. Araki et al. ${ }^{1}{ }^{1}$ have classified bainite into $\alpha_{B}$ and $\alpha_{B}^{\circ}$; the former bainite seems to be a structure occurred by recovering of $\alpha_{B}^{\circ}$. Under an electron microscope, $\alpha_{B}$ contains larger laths than $\alpha_{B}^{\circ}$. On the other hand, Krauss et $a l^{3)}$ observed a microstructure having laths of which size is larger than those of bainite. The dislocation density of this structure is similar to that of bainite, and he named such microstructure as granular ferrite. Therefore, it is necessary to examine the details of microstructures existing between $\alpha_{q}$ and $\alpha_{B}^{\circ}$ in the sequence of the change in microstructures. Furthermore, several researchers ${ }^{4,5)}$ reported that martensitic transformation occurs even in ultra-low carbon steels. Microstructural evidence, however, has not been enough. Recently Tsuzaki et al ${ }^{6}{ }^{6}$ proposed the mechanism for bainitic transformation. According to their mechanism, difference between bainitic and martensitic transformations decreases as the carbon content decreases. Therefore, it is important to make clear whether or not martensite is transformed from austenite even in ultralow carbon steels as a different microstructure from bainite. Finally, relation between these microstructures and mechanical properties has remained unclarified, whereas ultra-low carbon IF (interstitial free) steels have become one of important steels having high formability especially in automobile industries.

Considering the above mentioned background, the present work was carried out to elucidate microstructures, transformation behavior and the relation between microstructure and yielding behavior of ultra-low carbon steels.

\section{Experimental Procedures}

Chemical compositions of the steels subjected to the research are shown in Table 1. These steels were vacuum- 
Table 1. Chemical compositions of steels in mass $\%$.

\begin{tabular}{cccccccc}
\hline Steels & C & Si & Mn & P & S & Al & N \\
\hline A0 & 0.002 & 0.05 & 0.04 & 0.002 & 0.005 & 0.056 & 0.0038 \\
A1 & 0.01 & 0.05 & 0.06 & 0.003 & 0.005 & 0.057 & 0.0040 \\
A2 & 0.05 & 0.05 & 0.06 & 0.006 & 0.005 & 0.040 & 0.0051 \\
\hline B0 & 0.001 & 0.05 & 1.46 & 0.003 & 0.005 & 0.061 & 0.0048 \\
B1 & 0.01 & 0.05 & 1.46 & 0.003 & 0.005 & 0.060 & 0.0046 \\
B2 & 0.05 & 0.05 & 1.47 & 0.005 & 0.004 & 0.044 & 0.0037 \\
\hline
\end{tabular}

melted and hot-rolled to the sheet of $4 \mathrm{~mm}$ thickness by Sumitomo Metal Industries, Ltd. These steels are $\mathrm{Fe}-$ $\mathrm{C}$ (A series) and $\mathrm{Fe}-1.5 \mathrm{mass} \% \mathrm{Mn}-\mathrm{C}$ (B series) steels. For both series of steels, carbon content is changed at the three levels: 0.001 or $0.002,0.01$ and 0.05 mass $\%$. In the present paper, steels of the former two lower carbon contents ( $\leqq 0.01$ mass $\%)$ will be called as ultralow carbon steels. The sheets of $4 \mathrm{~mm}$ thickness were cut to $10 \times 20 \times 4 \mathrm{~mm}^{3}$ blanks for microscopy and $20 \times$ $90 \times 4 \mathrm{~mm}^{3}$ blanks for tensile test. After austenitizing at $1000^{\circ} \mathrm{C}$ for $20 \mathrm{~min}$, these blanks were quenched into iced brine (IBQ), quenched into water (WQ), cooled in air $(\mathrm{AC})$ or cooled in the furnace $(\mathrm{FC})$. Average cooling rates in the temperature range from 1000 to $400^{\circ} \mathrm{C}$ are about $360^{\circ} \mathrm{C} / \mathrm{s}(\mathrm{IBQ}), 150^{\circ} \mathrm{C} / \mathrm{s}$ (WQ), $5^{\circ} \mathrm{C} / \mathrm{s}$ (AC) and $1^{\circ} \mathrm{C} / \mathrm{min}$ (FC).

Optical microscopy was performed after polishing mechanically the surface layer by about $0.3 \mathrm{~mm}$ and etching chemically in a $2 \%$ nital. Transmission electron microscopy was carried out for thin foils cut from the center of the thickness of the sheet blanks. The foils were electrolytically polished in a solution of perchloric acid and ethanol of which temperature was controlled at room temperature and, for several foils, controlled in the range from -40 to $-50^{\circ} \mathrm{C}$. Microscopy was performed also for the specimens thinner than $4 \mathrm{~mm}$ which were heated $5 \mathrm{~min}$ at $1000^{\circ} \mathrm{C}$ in a vertical furnace and quenched in iced brine or water with a weight of $100 \mathrm{gf}$ at cooling rates higher than $360^{\circ} \mathrm{C} / \mathrm{s}$. The cooling rate was changed using specimens having various thickness and was monitored with a high speed recorder and thermocouples welded on the surface of the specimen. In Fig. 1, relation between specimen thickness and cooling rate is shown. Micro-Vickers hardness was measured under the load of $5 \mathrm{gf}$ for various microstructures in the specimens cooled at such higher rates. Hardness of more than eight points were measured per one microstructure and averaged.

Tensile tests were performed under the cross-head speed of $1 \mathrm{~mm} / \mathrm{min}$ at ambient temperature. Geometry of the tensile test specimen is shown in Fig. 2.

In order to observe the relation between $\gamma$ and $\alpha$ grain boundaries, $\alpha$ particle track etching method (ATE) of boron was carried out for Steel A0. Irradiation of neutrons was performed $12 \mathrm{~h}$ in the reactor of Rikkyo University. The procedures of this method has been shown in the previous paper. ${ }^{7)}$

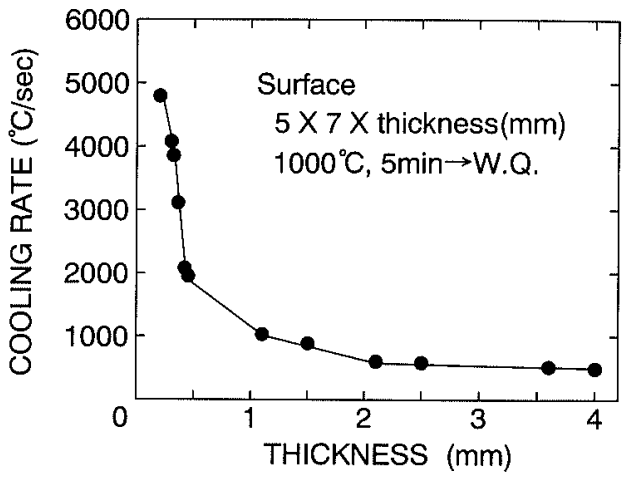

Fig. 1. Relation between specimen thickness and cooling rate.

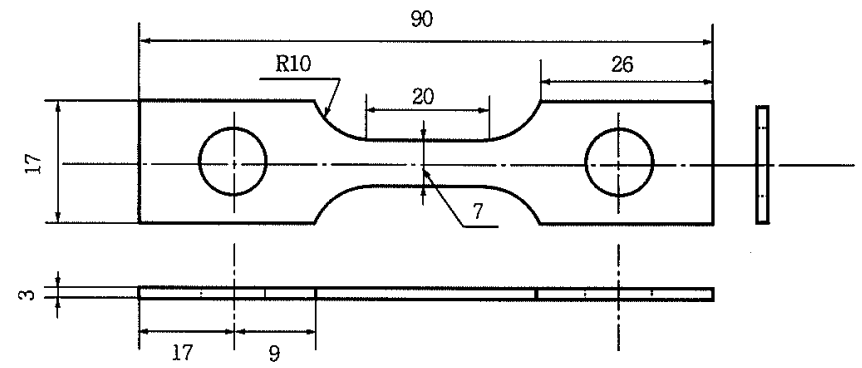

Fig. 2. Geometry of the specimen for tensile test.

\section{Results and Discussion}

\subsection{Effects of Cooling Rate Slower than $360^{\circ} \mathrm{C} / \mathrm{s}$ and Chemical Composition on Optical Microstructure}

Microstructures observed in the specimens cooled by IBQ and FC are shown in Figs. 3 and 4, respectively. The results are summarized in Table 2 together with results for the specimens cooled by WQ and AC. Any microstructures other than $\alpha_{p}$ (polygonal ferrite) and $\alpha_{q}$ (quasi-polygonal ferrite) were not observed in the ultra-low carbon steels cooled by all methods from IBQ to FC. In Steel A2, a small amount of pearlite was noticed in the specimens cooled by AC and FC together with $\alpha_{p}$. In Steel B2, with $\alpha_{\mathrm{p}}$, pearlite was observed in AC and FC specimens and with $\alpha_{p}$ or $\alpha_{q}$, bainite was observed in IBQ, WQ and AC specimens. It can be known from Table 2 that the fraction of $\alpha_{\mathrm{q}}$ increases with the cooling rate and the contents of $\mathrm{C}$ and $\mathrm{Mn}$.

Figure 5 shows the effects of cooling rate and chemical composition on ferrite grain size. In 0.01 and $0.05 \% \mathrm{C}$ steels, the grain size of IBQ and WQ specimens is smaller than that of FC specimens. However, in $0.001 \%$ C (B0) and $0.002 \% \mathrm{C}(\mathrm{A} 0)$ steels such a cooling rate dependence cannot be observed. Two reasons for this fact can be speculated. One is that the mechanism for the austenite $\rightarrow$ ferrite transformation in ultra-low carbon steels is different from the ordinary nucleation and growth mechanism. The other is that in ultra-low carbon steels the growth rate of ferrite is very fast comparing with the nucleation rate.

As for the former reason, it is speculated that the dependence of grain size on cooling rate is reversed if the massive transformation occurs at higher cooling rate. ${ }^{8)}$ As for the latter reason, Wilson ${ }^{9)}$ has suggested that the $\gamma \rightarrow \alpha$ transformation can be conceived to be growth controlled reaction when the growth of $\alpha$ grain 


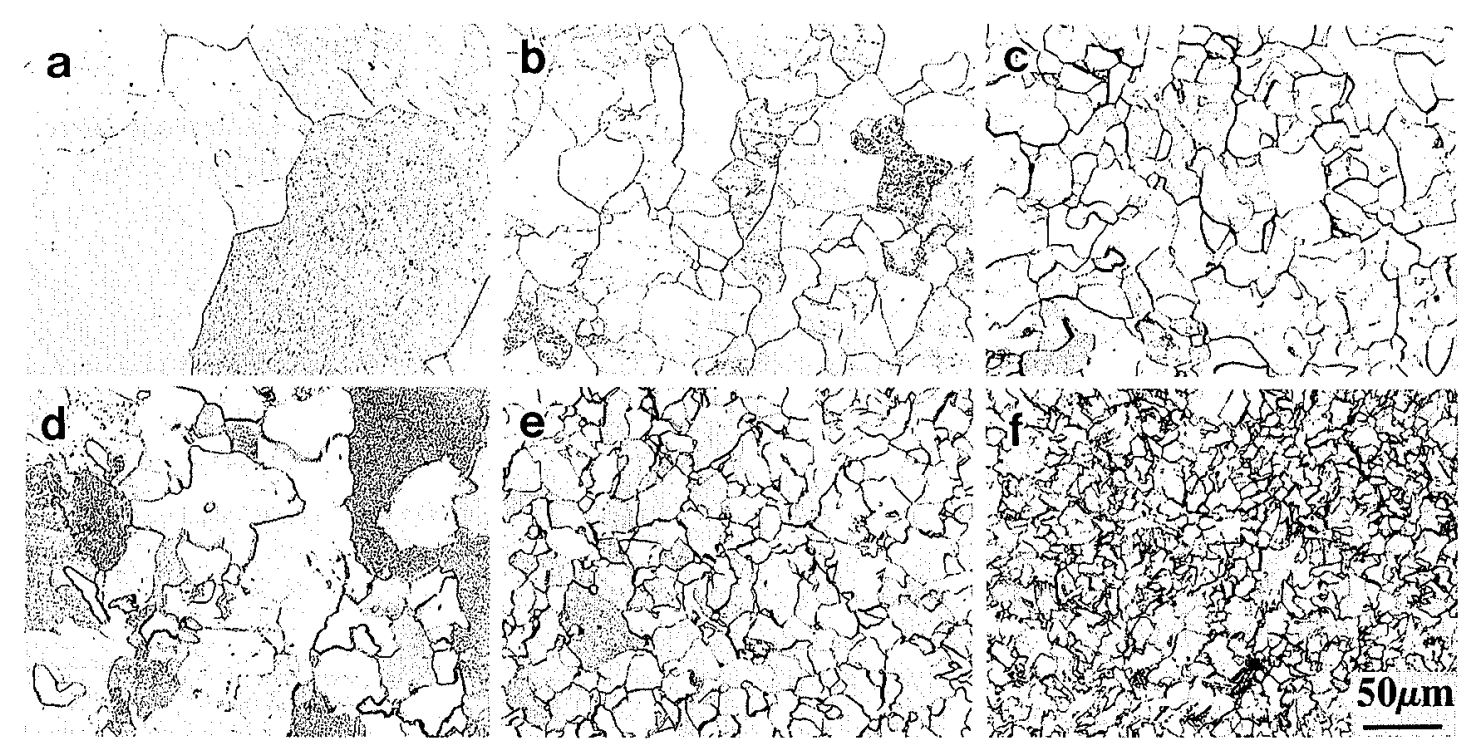

Fig. 3. Effects of composition on optical microstructure of $4 \mathrm{~mm}$ thick specimens cooled by IBQ. (a) A0, (b) $\mathrm{Al}$, (c) A2, (d) B0, (e) B1 and (f) B2.

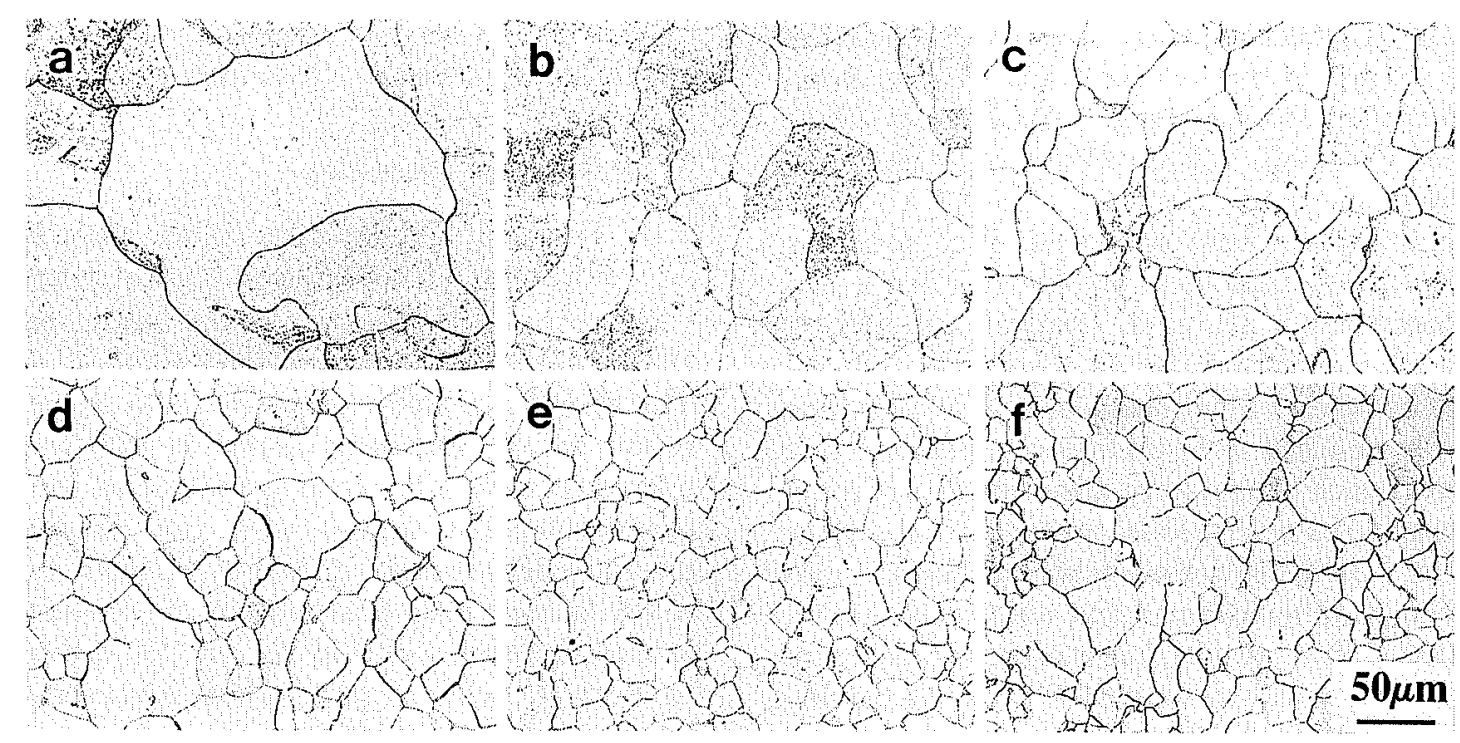

Fig. 4. Effects of composition on optical microstructure of $4 \mathrm{~mm}$ thick specimens cooled by FC. (a) A0, (b) Al, (c) A2, (d) B0, (e) BI and (f) B2.

Table 2. Effects of composition and cooling rate on optical microstructure of $4 \mathrm{~mm}$ thick specimens heated $20 \mathrm{~min}$ at $1000^{\circ} \mathrm{C}$.

\begin{tabular}{|c|c|c|c|c|}
\hline Steels & $\begin{array}{c}\text { IBQ } \\
\left(360^{\circ} \mathrm{C} / \mathrm{s}\right)\end{array}$ & $\begin{array}{c}\text { WQ } \\
\left(150^{\circ} \mathrm{C} / \mathrm{s}\right)\end{array}$ & $\begin{array}{c}\mathrm{AC} \\
\left(5^{\circ} \mathrm{C} / \mathrm{s}\right)\end{array}$ & $\begin{array}{c}\mathrm{FC} \\
\left(1^{\circ} \mathrm{C} / \mathrm{min}\right)\end{array}$ \\
\hline $\begin{array}{l}\mathrm{A} 0(0.002 \mathrm{C}) \\
\mathrm{A} 1(0.01 \mathrm{C}) \\
\mathrm{A} 2(0.05 \mathrm{C})\end{array}$ & $\begin{array}{l}\alpha_{p}+\alpha_{q} \\
\alpha_{p}+\alpha_{q} \\
\alpha_{p}+\alpha_{q}\end{array}$ & $\begin{array}{l}\alpha_{p}+\alpha_{q} \\
\alpha_{p}+\alpha_{q} \\
\alpha_{p}+\alpha_{q}\end{array}$ & $\begin{array}{c}\alpha_{\mathrm{p}} \\
\alpha_{\mathrm{p}} \\
\alpha_{\mathrm{p}}(+\mathrm{P})\end{array}$ & $\begin{array}{c}\alpha_{p} \\
\alpha_{p} \\
\alpha_{p}(+P)\end{array}$ \\
\hline $\begin{array}{l}\text { B0 }(1.5 \mathrm{Mn}-0.001 \mathrm{C}) \\
\text { B1 }(1.5 \mathrm{Mn}-0.01 \mathrm{C}) \\
\text { B2 }(1.5 \mathrm{Mn}-0.05 \mathrm{C})\end{array}$ & $\begin{array}{l}\alpha_{q}+\alpha_{p} \\
\alpha_{q}+\alpha_{p} \\
\alpha_{q}+\alpha_{B}^{\circ} \\
+\alpha_{B}\end{array}$ & $\begin{array}{r}\alpha_{q}+\alpha_{p} \\
\alpha_{q}+\alpha_{p} \\
\alpha_{q}+\alpha_{B}^{0} \\
+\alpha_{B}\end{array}$ & $\begin{array}{c}\alpha_{\mathrm{p}} \\
\alpha_{\mathrm{p}} \\
\alpha_{\mathrm{p}}\left(+\mathrm{P}+\alpha_{\mathrm{B}}^{\circ}\right. \\
\left.+\alpha_{\mathrm{B}}\right)\end{array}$ & $\begin{array}{c}\alpha_{p} \\
\alpha_{p} \\
\alpha_{p}(+P)\end{array}$ \\
\hline
\end{tabular}

( ): small amount

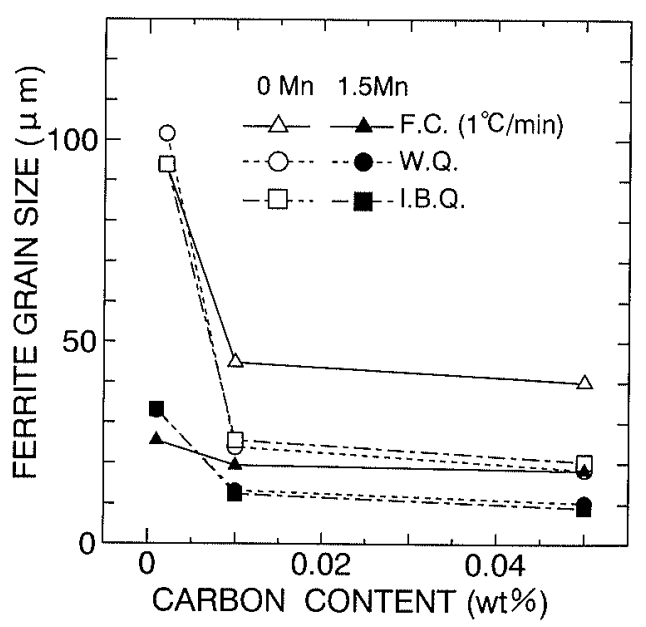

Fig. 5. Effects of cooling rate and chemical composition on ferrite grain size. 
occurs by atom transfer across incoherent boundaries: the rate of transfer can be thought to be the same as that for grain boundary diffusion. In such a reaction, the normal cooling rate dependence of grain size cannot be expected.

Concerning the massive transformation, Massalski ${ }^{10}$ defined the massive transformation as the reaction having much less dependence on semicoherency during the nucleation stages and, in many cases, involving only the growth of high energy incoherent boundaries as evidenced by the random crossing of parent boundaries. And he mentioned that the resultant microstructure may consist of random equi-axed grains but grain boundaries may be more jagged. The school of Hillert ${ }^{8,11)}$ have also thought interfaces between massive ferrite and $\gamma$ are incoherent. On the other hand, Wilson ${ }^{9)}$ has thought that massive ferrite nucleates as a semispherical cap on grain faces, with a planar coherent surface and an upper curved incoherent boundary and this kind of ferrite grows by movement of the incoherent boundary: similar to the mechanism of nucleation and growth of proeutectoid ferrite. Maki ${ }^{12)}$ is also thinking that massive ferrite has coherent boundaries with at least one of the parent grains and shows similar growing characteristics to common diffusional transformations. The present authors, however, think that there is a lack of experimental data on massive ferrite and massive transformation, as Edmonds ${ }^{14)}$ has mentioned. As for the massive ferrite, an important confusion should be suggested. The optical micrograph shown by Wilson ${ }^{9)}$ as equiaxed ferrite, which was thought by him as the product of nucleation and growth mechanism, has been referred by Nishiyama ${ }^{13)}$ and $\mathrm{Maki}^{12)}$ as a typical massive structure.

On the other hand, the present authors think that using the term "equi-axed ferrite" contrastingly with the term "massive ferrite" in classification of microstructures is not reasonable. Based on the terminology by Araki and Shibata, ${ }^{1)}$ such ferrite is classified into $\alpha_{\mathbf{q}}$.

In order to know the reason for the abnormal cooling rate dependence of grain size, the present authors tried to obtain the information concerning the relation between $\gamma$ and $\alpha$ grain boundaries by following three experiments: (1) optical microscopy with a microscope having hot stage, (2) observation of $\gamma$ boundaries grooved thermally or oxidized in the austenite region and (3) observation of $\gamma$ boundaries through autoradiography of boron. As for the first experiment, it failed due to the difficulty in observing $\gamma$ grain boundaries. In the second experiment, optical micrographs as shown in Fig. 6 were obtained. From such micrographs, certain information about the relation between $\gamma$ and $\alpha$ grain boundaries can be obtained. However, it was difficult to reveal enough number of $\gamma$ grain boundaries for analyzing the relation between $\gamma$ and $\alpha$ grain boundaries. In the third experiment, clear ATE micrographs could be obtained for Steel $\mathrm{A} 0$ cooled by $\mathrm{AC}\left(5^{\circ} \mathrm{C} / \mathrm{s}\right)$, whereas boron was not alloyed in this steel. Such ATE image showing boron segregation along grain boundaries was not observed in the specimens cooled at the faster rate. Two examples of ATE micrographs are shown with their coincident

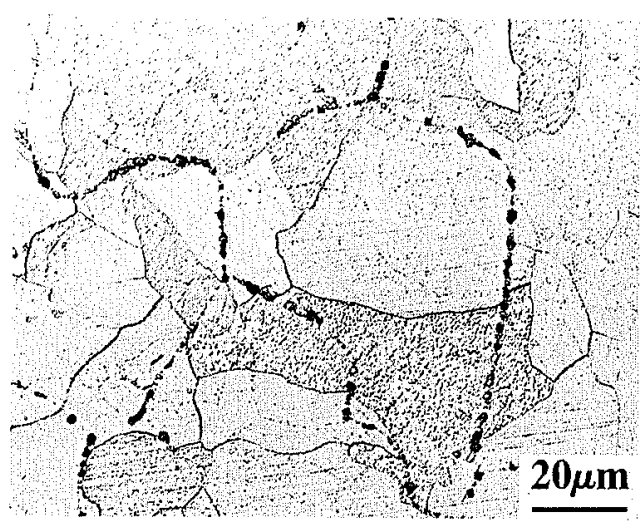

Fig. 6. Optical micrograph of Steel A0 slightly oxidized at $1000^{\circ} \mathrm{C}$.

chemical etching micrographs in Fig. 7. Comparing with ATE and chemical etching micrographs, it can be known that the position and the shape of the boundaries revealed in ATE micrographs are same with boundaries observed in the coincident chemical etching micrographs. Therefore, the grain boundaries revealed in ATE micrographs are $\alpha$ grain boundaries, that is to say, the trial failed to observe $\gamma$ grain boundaries. It could be known, however, that boron does not segregate on every $\alpha$ grain boundary as shown in Fig. 7. Boron generally tends to segregate on incoherent boundaries and not to segregate on coherent ones. Therefore, the results of ATE shows that not a small fraction of $\alpha$ grain boundaries are coherent ones. This fact presents a new unclarified problem in the transformation behavior in ultra-low carbon steels. Because, it is difficult to consider the process in which two $\alpha$ grains come in contact and form a coherent boundary between them at relatively high probability.

\subsection{Effects of Cooling Rate Slower than $360^{\circ} \mathrm{C} / \mathrm{s}$ and Chemical Composition on TEM Microstructure}

It was observed that the dislocation density in $\alpha_{\mathrm{q}}$ is higher than that in $\alpha_{p}$ as shown in Fig. 8. In $\alpha_{q}$, dislocations tend to form cell structures, whereas dislocations which do not form cell structures were also observed as shown in Fig. 9.

In Steel A2, pearlite could be observed even in the specimens cooled by IBQ under an electron microscope. Figure 10 is exhibiting such pearlite.

Figure 11 is showing bainite structures observed in Steel B2 cooled by IBQ. The dislocation density of the structure of the central region is low and precipitates in lines can be observed. Such characteristics of this microstructure are not similar to those of granular ferrite reported by Krauss. ${ }^{3}$ From these appearance, we conceived that this structure is recovered bainite $\left(\alpha_{\mathrm{B}}\right)$. Microstructures around this $\alpha_{B}$ contain high density dislocations and laths; they can be called as $\alpha_{\mathrm{B}}^{\circ}$. In the present works, microstructure similar to granular ferrite reported by Krauss was not observed.

On the other hand, even in Steels A0 and B0 cooled by IBQ precipitates of cementite were observed on ferrite grain boundaries as shown in Figs. 12,13 and 14. Some diffraction patterns were analyzed to be near to the Pitsch 

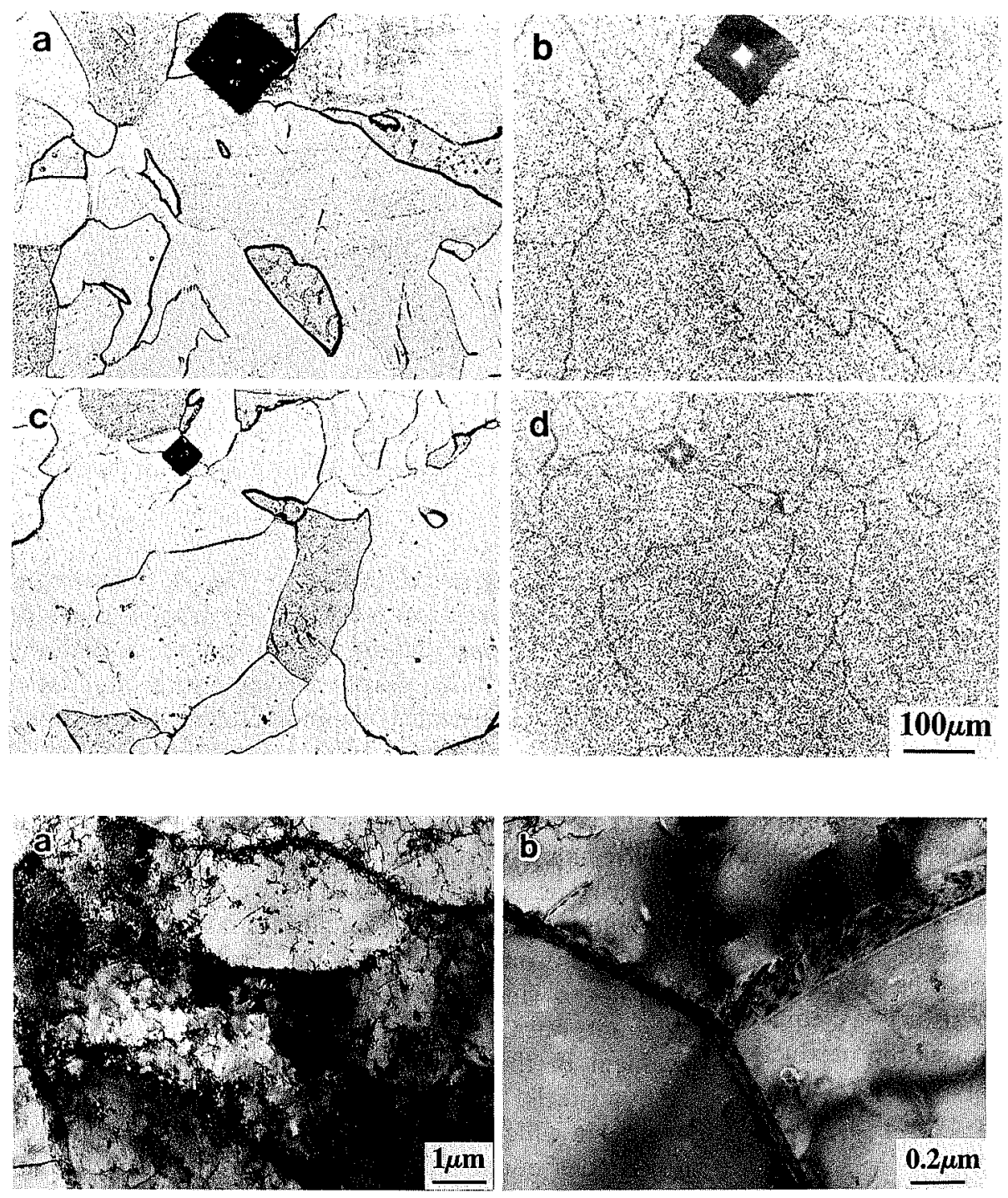

Fig. 7.

Coincident chemical etching (a and $c$ ) and $\alpha$ track etching ( $b$ and $d$ ) micrographs of Steel A0 cooled by AC.
Fig. 8.

TEM microstructures observed in Steel A0 cooled by IBQ.

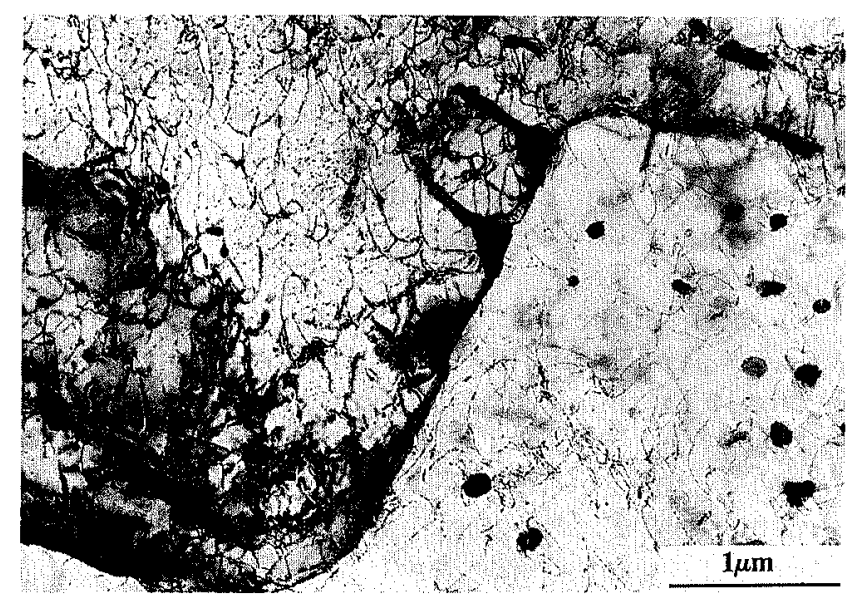

Fig. 9. TEM microstructure observed in Steel B2 cooled by IBQ.

relation between $\alpha$ and cementite. In these steels, the $\gamma \rightarrow$ $\alpha$ transformation occurs in the $\alpha$ single-phase field. Therefore, such precipitation of cementite is not easy to be explained. So far, two explanations have been speculated. One is the explanation by the increase in carbon content along $\gamma / \alpha$ interface during the $\gamma \rightarrow \alpha$ transformation by certain reasons. The other is the ex-

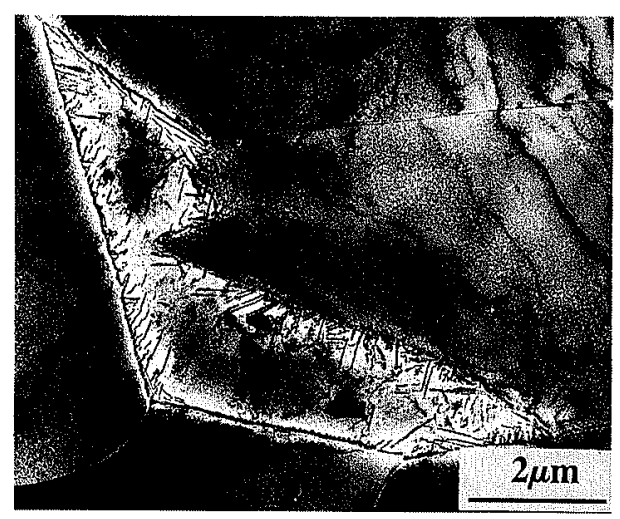

Fig. 10. Pearlite observed in Steel A2 cooled by IBQ.

planation by carbon transfer from $\alpha$ to $\gamma$ by the difference of chemical potential of carbon between $\gamma$ and $\alpha$. In both explanations, the carbon content in $\gamma$ phase retained between two $\alpha$ phases increases to the level higher than the solubility limit of cementite.

As for the former explanation, the dragging effects by carbon were proposed through local equilibrium model in the papers ${ }^{8,11)}$ discussing the mechanism for partitionless heterogeneous phase transformation such a $\gamma \rightarrow \alpha$ transformation in $\alpha$ single-phase field. According 


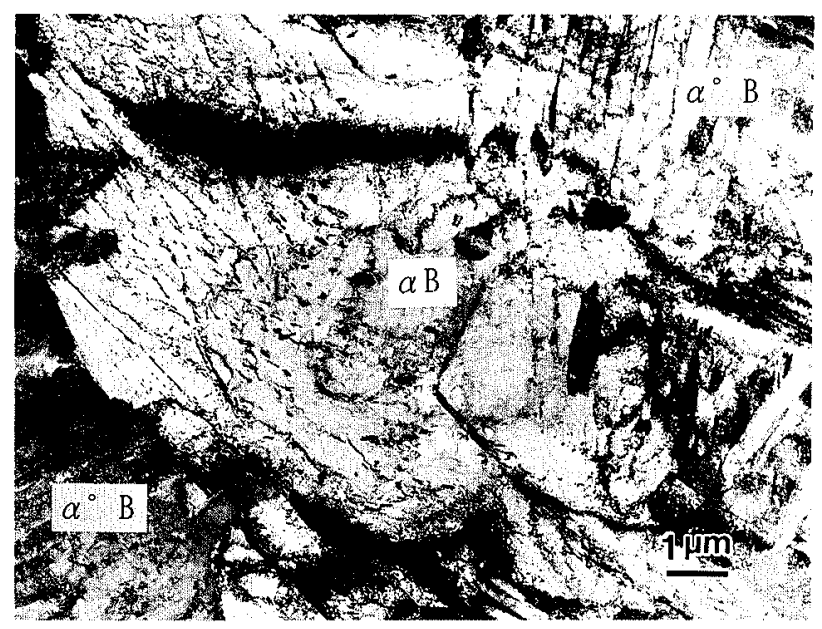

Fig. 11. Bainite observed in Steel B2 cooled by IBQ. to these papers, the content of carbon in the interface region is higher than those of $\gamma$ and $\alpha$ matrices, and carbon atoms move with the interfaces even at high growth rate of about $10^{3} \mu \mathrm{m} / \mathrm{s}$. Araki and Shibata ${ }^{14)}$ have also thought that a similar dragging is occurred by the driving force for carbon segregation to the interface region which contains defects and has high free energy. Figure 15 is a schematic draw of carbon profile near a moving $\gamma / \alpha$ interface. ${ }^{15)}$ Concerning the latter explanation, Maki and Tsuzaki ${ }^{16)}$ proposed a thermodynamical model to explain the formation of M/A constituent in ultra-low carbon steels. In their model, gradient of chemical potential of carbon occurs between $\gamma$ and $\alpha$ phases and therefore carbon content increases in $\gamma$ even in the reaction in $\alpha$ single phase field. If such a mechanism can work in the formation of M/A constituent, similar
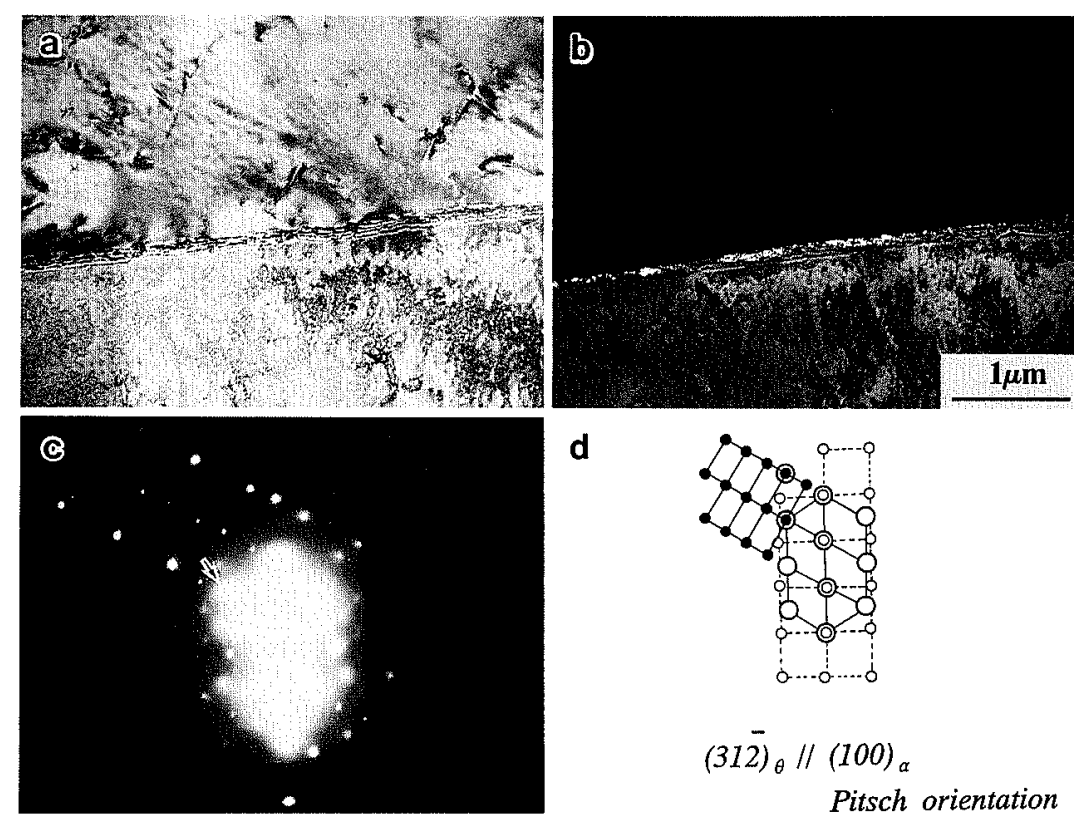

d

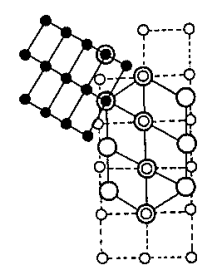

$\begin{aligned}(31 \overline{2})_{\theta} / / & (100)_{\alpha} \\ & \text { Pitsch orientation }\end{aligned}$

Fig. 12.

Cementite observed on grain boundary in Steel A0 cooled by IBQ . (a) bright field image, (b) dark field image and (c) diffraction pattern, electrolytically etched at ambient temperature.
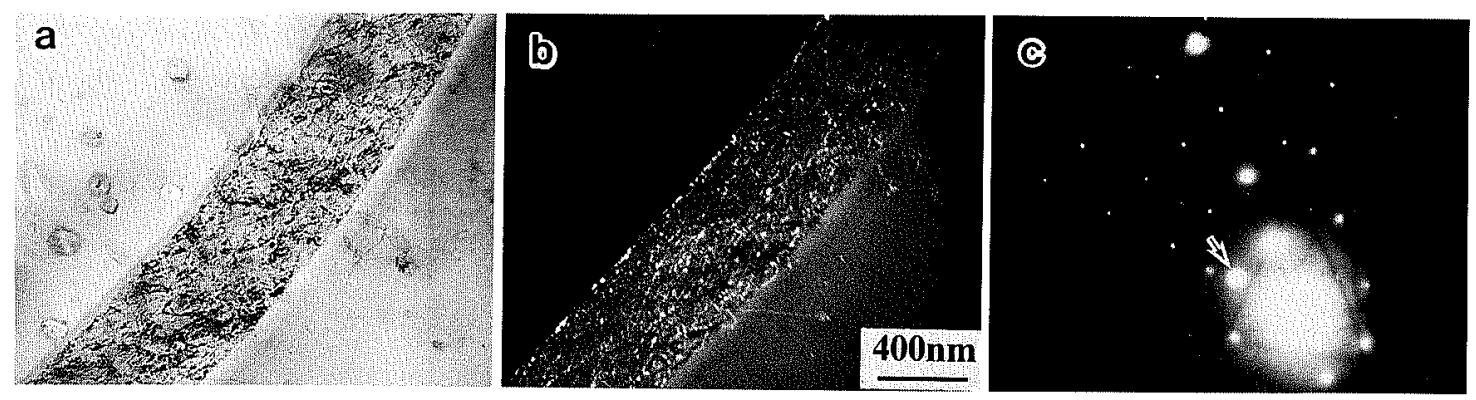

Fig. 13. Cementite observed on grain boundary in Steel A0 cooled by IBQ. (a) bright field image, (b) dark field image and (c) diffraction pattern, electrolytically etched at ambient temperature.
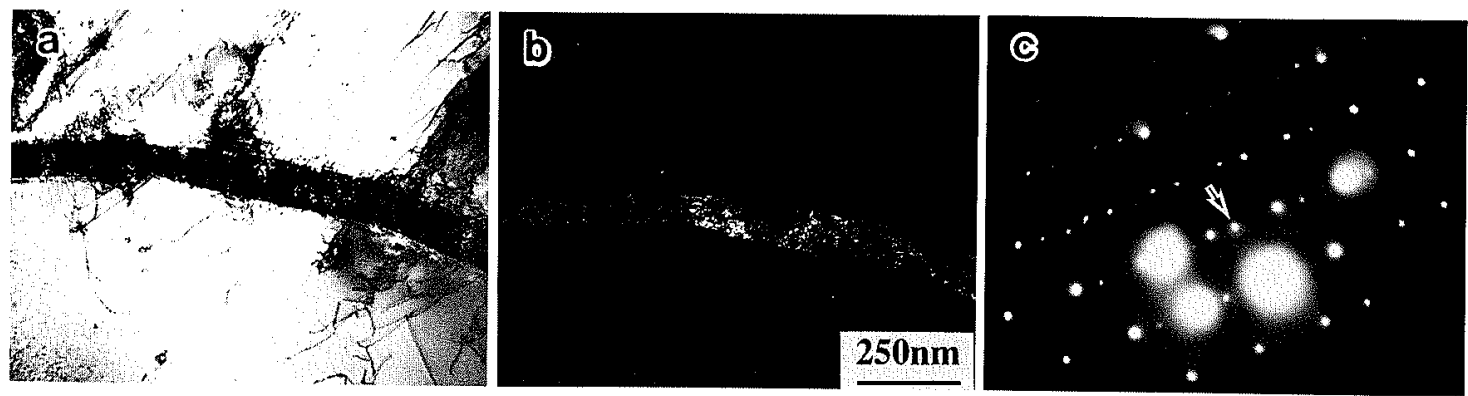

Fig. 14. Cementite observed on grain boundary in Steel A0 cooled by IBQ. (a) bright field image, (b) dark field image and (c) diffraction pattern, electrolytically etched at $-40^{\circ} \mathrm{C}$. 
mechanism is contributable to the carbon transfer to $\gamma$ during $\alpha$ formation and also the cementite precipitation in $\alpha$ single-phase field.

\subsection{Relation between Microstructures and Yielding Behavior}

Effects of microstructures through composition and cooling rate on yielding behavior are shown in Table 3.

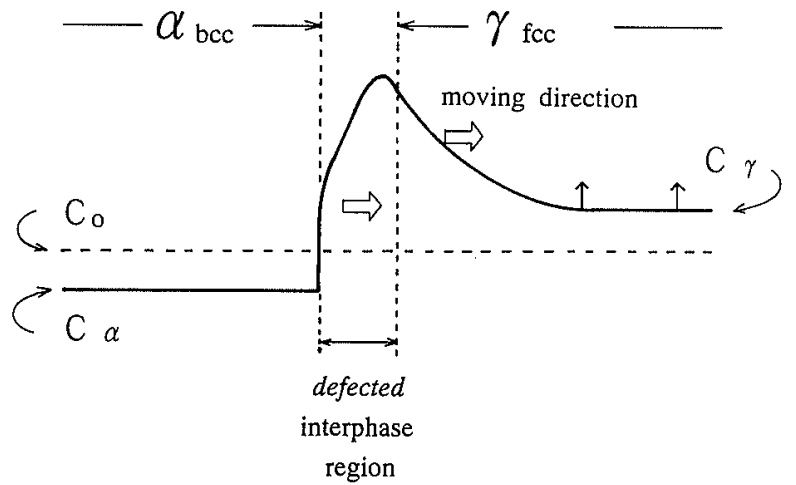

Fig. 15. Schematic draw of carbon distribution $\left(C_{\alpha}\right.$ and $\left.C_{\gamma}\right)$ near moving interface between austenite and ferrite. ${ }^{15)} C_{0}$ is the initial content of carbon.

Table 3. Effects of composition and cooling rate on yielding behavior.

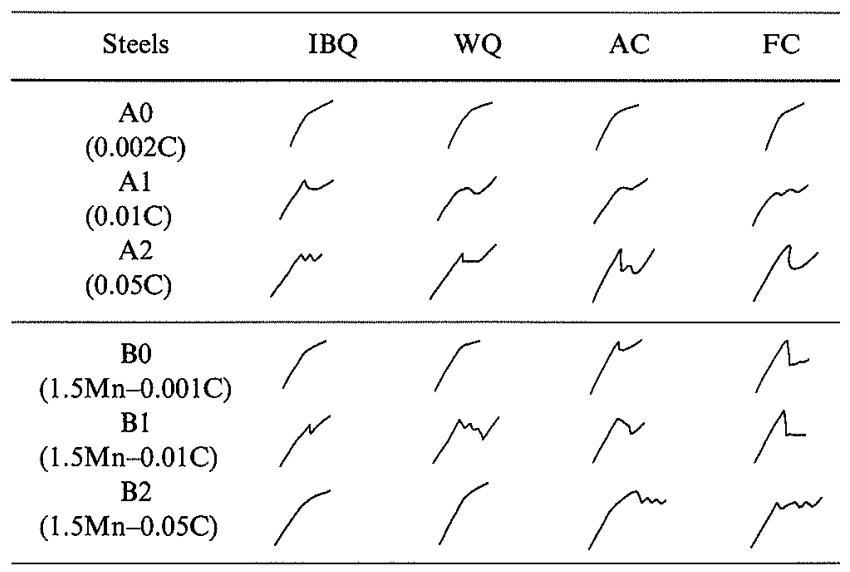

This table shows that discontinuous yielding tends to occur with an increase in carbon content. Comparing this table with Table 2, however, it is known that this tendency is suppressed by the mixing of bainitic structure. It is generally known that mixing of bainite enhance discontinuous yielding. In such case, however, bainite is produced by isothermal holding. The result of the present work reveals that bainite transformed during continuous cooling shows the reverse effect. Such opposite effects are attributable to the difference in the degree of carbon segregation to dislocations which are produced during bainitic transformation. Carbon can pin down effectively dislocations during isothermal holding, whereas carbon atoms have not enough time to segregate to dislocations during continuous cooling, especially during rapid cooling.

Table 3 also shows that manganese tends to enhance the occurrence of discontinuous yielding. In low alloy steels, it is known that manganese suppresses strain aging by decreasing the diffusion of carbon atoms through the attractive interaction force with carbon. ${ }^{17)}$ Furthermore, manganese narrows the solubility limit of cementite as reported by Smith. ${ }^{18)}$ Indeed, in Steels B0 and B1 cooled by $\mathrm{AC}$ and $\mathrm{FC}$, fine intragranular precipitates, which are maybe cementite, could be observed under an electron microscope. If the fraction of carbon contributable to pinning dislocations is reduced by such cementite precipitation, the discontinuous yielding should be suppressed. Therefore, the reason for the enhancing effect of manganese on discontinuous yielding has not been clear. As one of the reasons, it is speculated that the $\mathrm{Mn}-\mathrm{C}$ complexes are effective on pinning dislocations. Further researches, however, are required.

\subsection{Optical Microstructures and Microhardness of Specimens Cooled Faster than $360^{\circ} \mathrm{C} / \mathrm{s}$}

Typical optical microstructures observed in specimens cooled faster than $360^{\circ} \mathrm{C} / \mathrm{s}$ are exhibited in Figs. 16 and 17 for Steel A0 and Steel B0, respectively.

In Steel A0, bainite is observed at about $3900^{\circ} \mathrm{C} / \mathrm{s}$

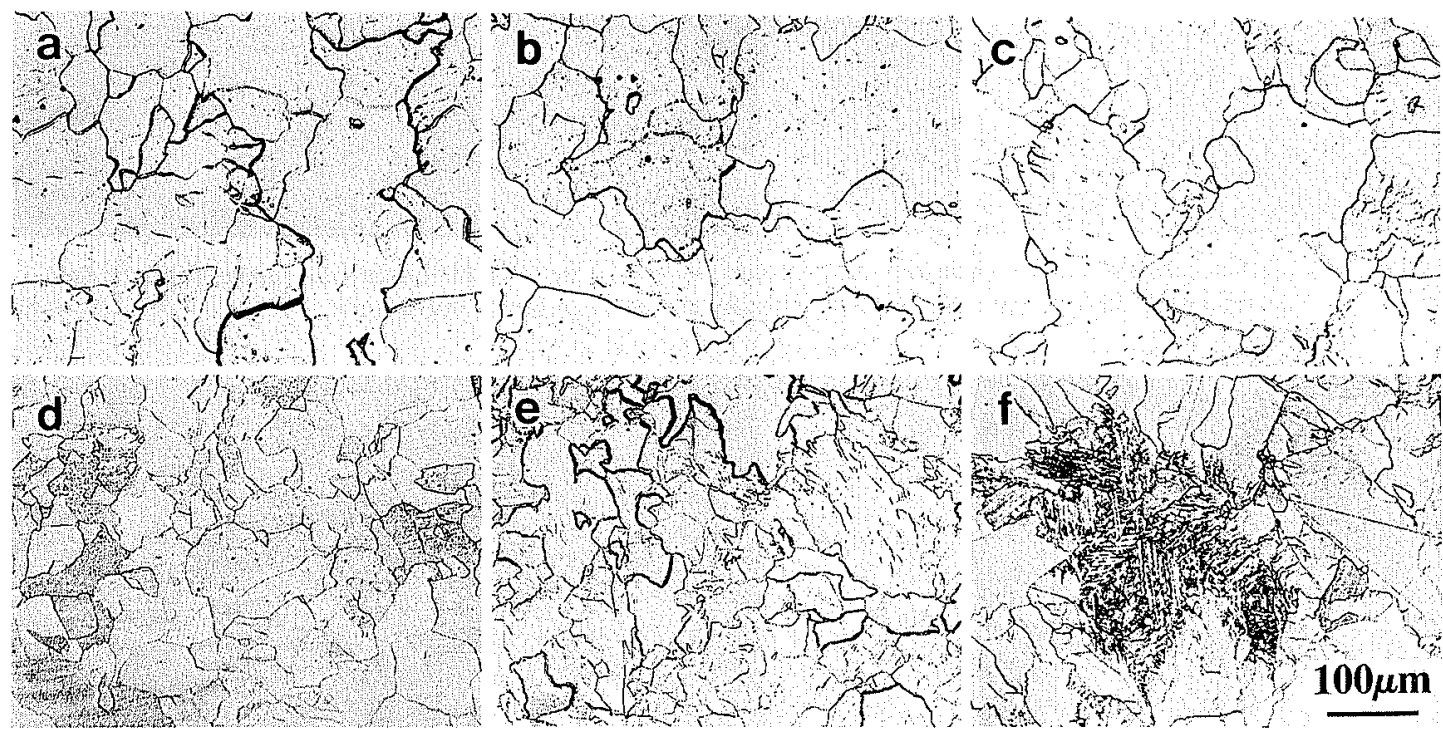

Fig. 16. Effects of rapid quench on optical microstructures of Steel $\mathrm{A} 0$. (a) $500^{\circ} \mathrm{C} / \mathrm{s}$, (b) $600^{\circ} \mathrm{C} / \mathrm{s}$, (c) $1000^{\circ} \mathrm{C} / \mathrm{s}$, (d) $2100^{\circ} \mathrm{C} / \mathrm{s}$, (e) $3100^{\circ} \mathrm{C} / \mathrm{s}$ and (f) $3900^{\circ} \mathrm{C} / \mathrm{s}$. 

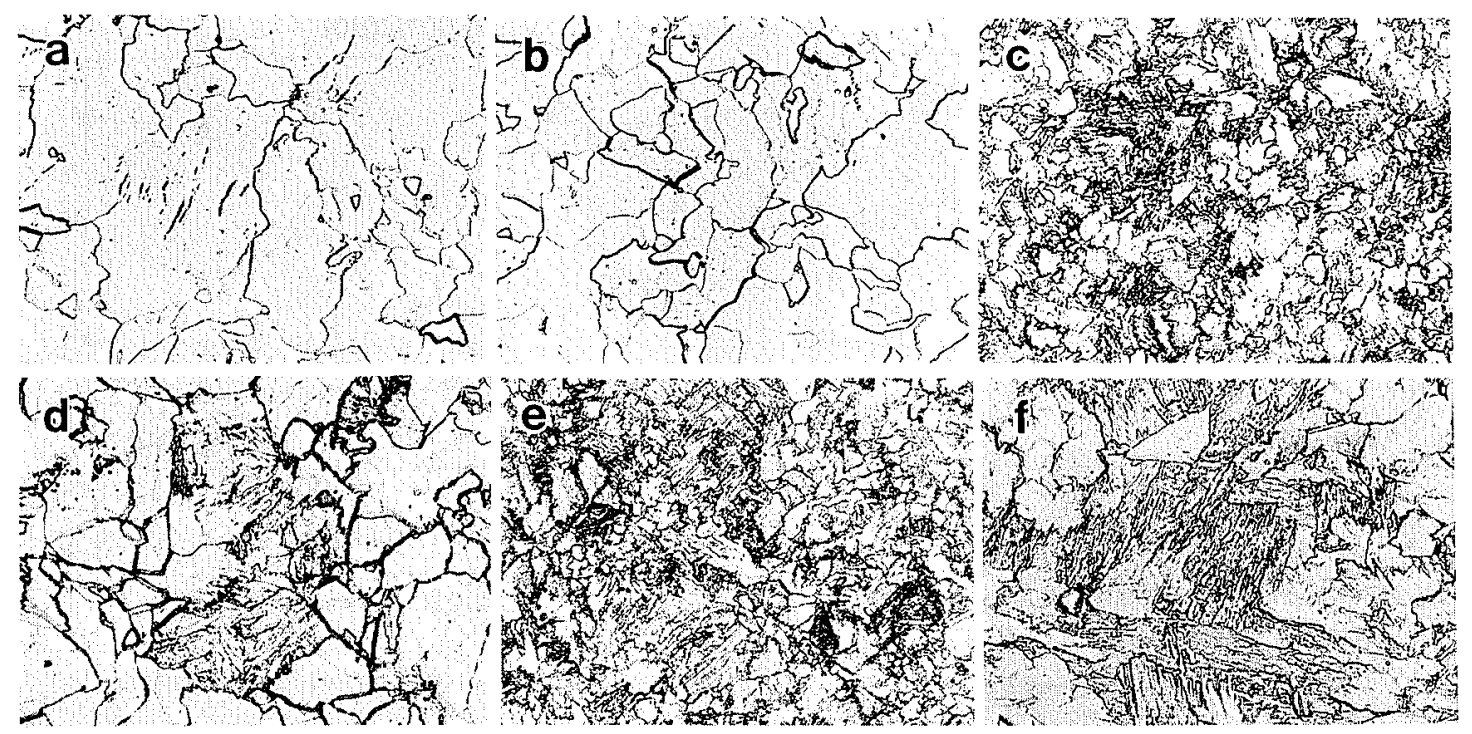

a $\sim \mathrm{c}, \mathrm{e} ; 100 \mu \mathrm{m} \quad \mathrm{d}, \mathbf{f} ; \mathbf{5 0 \mu \mathrm { m }}$

Fig. 17. Effects of rapid quench on optical microstructures of Steel $\mathrm{B} 0$. (a) $500^{\circ} \mathrm{C} / \mathrm{s}$, (b) $750^{\circ} \mathrm{C} / \mathrm{s}$, (c) $2700^{\circ} \mathrm{C} / \mathrm{s}$, (d) $2700^{\circ} \mathrm{C} / \mathrm{s}$, (e) $3200^{\circ} \mathrm{C} / \mathrm{s}$ and (f) $3200^{\circ} \mathrm{C} / \mathrm{s}$.

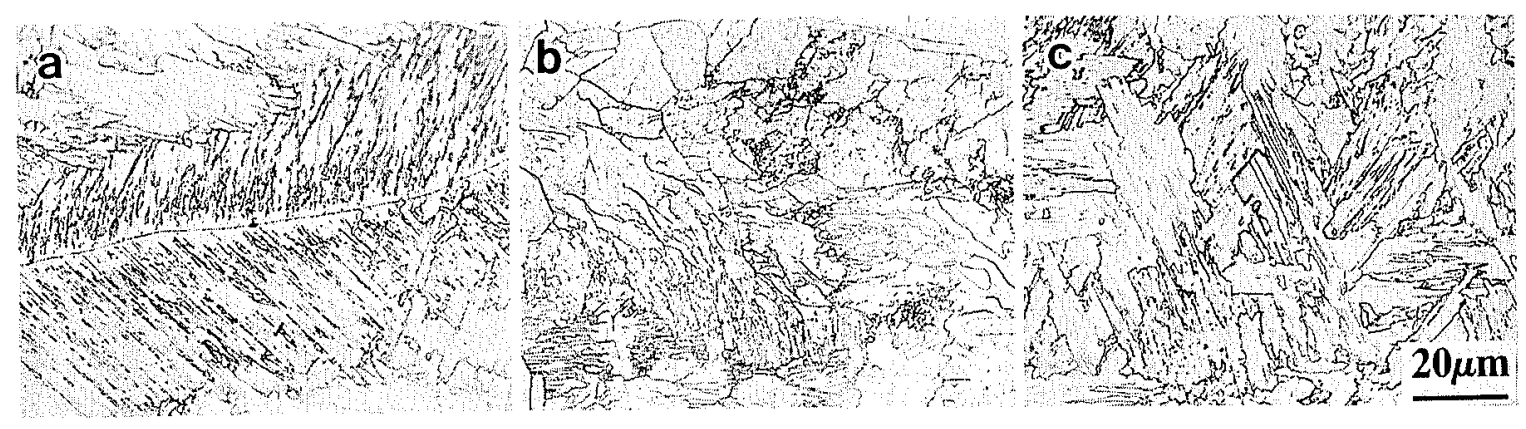

Fig. 18. Optical microstructures observed in Steel A0 cooled at 3900 and $4800^{\circ} \mathrm{C} / \mathrm{s}$.

together with $\alpha_{\mathrm{q}}$, while at about $3100^{\circ} \mathrm{C} / \mathrm{s} \alpha_{\mathrm{q}}$ is main structure. As for Steel B0, bainite can be observed in the specimens cooled faster than about $2700^{\circ} \mathrm{C} / \mathrm{s}$. These cooling rates are for the specimen surface as mentioned in the previous chapter.

Bainite of ultra-low carbon steels shows several features as shown in Fig. 18. Lath-like substructures are observed in the matrix of $\alpha_{q}$ as shown in the left region of Fig. 18(b). This region shows the continuous change in microstructure from $\alpha_{\mathrm{q}}$ to bainite with increasing the density of the lath-like substructure. Such appearance shows that the front of the moving $\gamma / \alpha$ interface is severely curved at the scale of lath. From those observations, following sequence of the microstructure change is conceivable: at a certain cooling rate austenite transforms to $\alpha_{q}$ at the early stage during cooling and then the tendency of producing lath-like substructure increases at the moving $\gamma / \alpha$ interface as the temperature decreases: finally bainitic structure is produced at the interface when the temperature becomes low enough. It is thought that martensite is produced after the occurrence of bainite in the sequence of the microstructure change if the cooling rate is desirable. As for terminology, it is difficult how to call the above mentioned intermediate structure between $\alpha_{\mathrm{q}}$ and bainite. Therefore, in the present work,

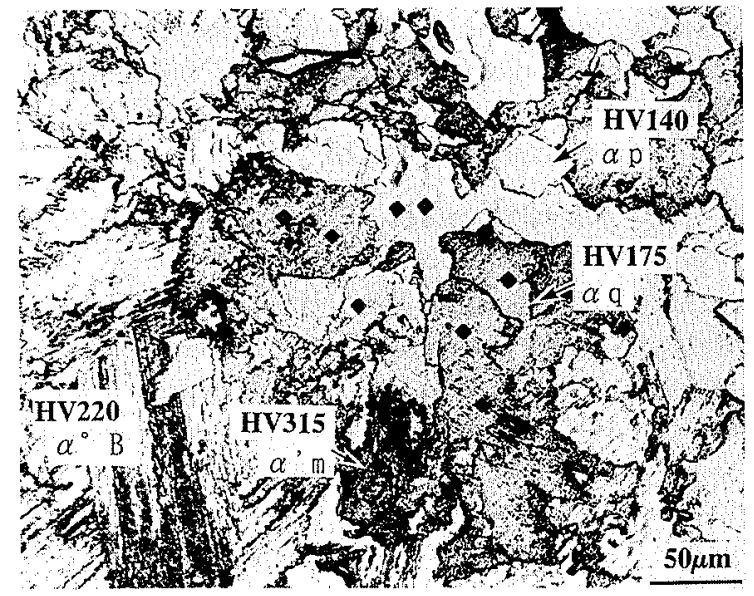

Fig. 19. Optical microstructures observed and microhardness of Steel A0 cooled at $4800^{\circ} \mathrm{C} / \mathrm{s}$.

there remains a certain ambiguity in determination of the boundary between $\alpha_{\mathrm{q}}$ and $\alpha_{\mathrm{B}}^{\circ}$ (or $\alpha_{\mathrm{B}}$ ).

Microstructure in Fig. 18(c) is similar to that of lath martensite. From the microhardness, however, such structure was classified into bainite.

The specimen cooled at the highest rate in the present work contains many microstructures and shows very 

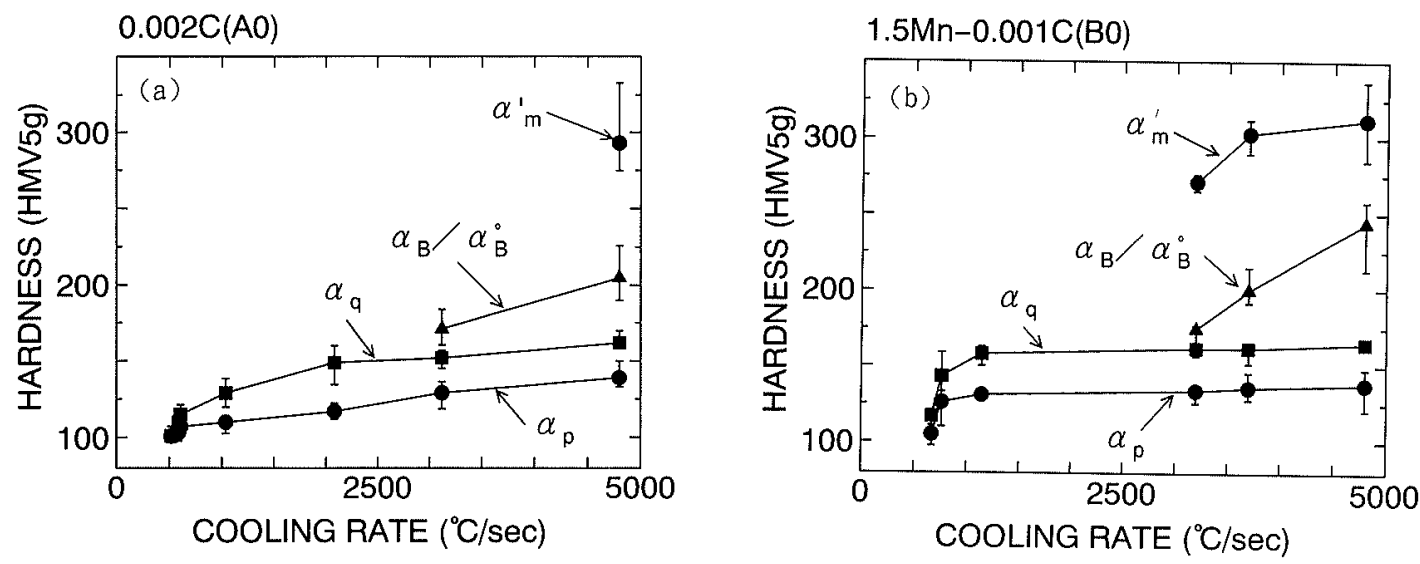

Fig. 20. Effects of cooling rate on microstructures and hardness of Steels A0 and B0.
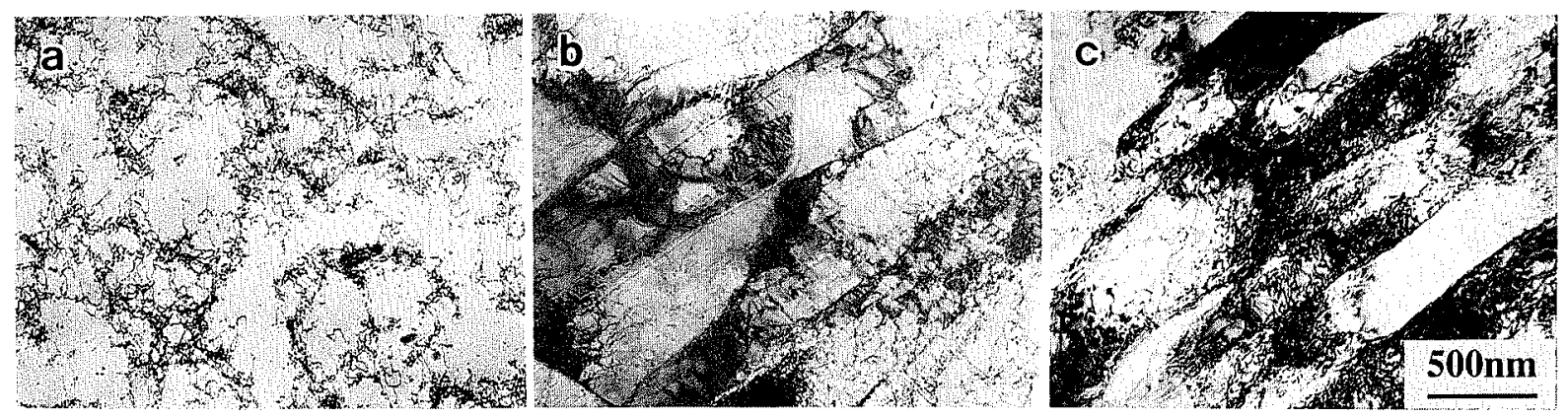

Fig. 21. Change of microstructures in ferrite matrix of Steel $\mathrm{B} 0$ with cooling rate. (a) $510^{\circ} \mathrm{C} / \mathrm{s}$, (b) $2100^{\circ} \mathrm{C} / \mathrm{s}$ and (c) $3100^{\circ} \mathrm{C} / \mathrm{s}$.

complicated features. Especially, it is difficult to distinguish martensite from bainite only by optical microscopy. By microhardness measurement, it was known that $\alpha_{p}, \alpha_{q}$ and bainite show each hardness level. Using such knowledge, martensite can be distinguished from bainite as shown in Fig. 19. The microstructure identified as martensite in Fig. 19 shows clearly higher hardness than that of bainite. Optical microstructures and their microhardness of the specimens cooled at high rates are summarized in Fig. 20.

\subsection{TEM Microstructures of Specimens Cooled Faster than $360^{\circ} \mathrm{C} / \mathrm{s}$}

In the above section, intermediate optical microstructures between $\alpha_{q}$ and bainite were mentioned. Figure 21 shows the change of TEM microstructures of ferrite matrix of Steel B0 with cooling rate. The change in microstructure from $\alpha_{q}$ to bainite with an increase in cooling rate can be observed.

By the electron microscopy, martensite could be distinguished from bainite. Okamoto et al. ${ }^{18)}$ have compared lath widths of bainite and martensite which are transformed in a $0.04 \% \mathrm{C}-3 \% \mathrm{Mn}$ steel by isothermal holding and by quenching, respectively. According to their results, martensite lath width was about $0.2 \mu \mathrm{m}$ as the mean value, whereas the mean lath width of bainite transformed at $400^{\circ} \mathrm{C}$ was about $0.5 \mu \mathrm{m}$.

Figure 22 shows microstructure observed in Steel A0 quenched at $4800^{\circ} \mathrm{C} / \mathrm{s}$. The mean width of the laths is about $0.4 \mu \mathrm{m}$ and seems to be a little thicker than that of martensite observed by Okamoto et al. The lath width,

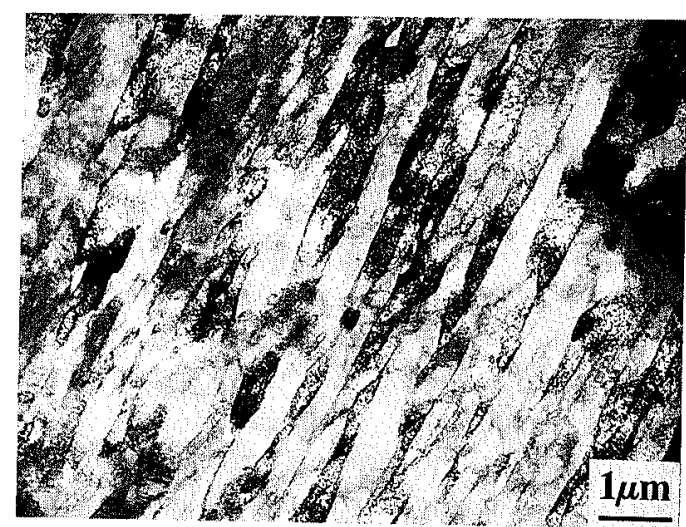

Fig. 22. Martensite observed in Steel A0 cooled at $4800^{\circ} \mathrm{C} / \mathrm{s}$.

however, is thinner and the dislocation density is higher comparing with bainite observed in Steel A0.

Figure 23 is showing microstructures observed in Steel B1 cooled at 1600 and $640^{\circ} \mathrm{C} / \mathrm{s}$. They can be called as martensite (a) and bainite (b), respectively, from the similar reasons mentioned above for Fig. 22.

\section{Conclusion}

Results can be summarized as follows. In the case of the cooling slower than $360^{\circ} \mathrm{C} / \mathrm{s}$, any microstructures other than $\alpha_{p}$ and $\alpha_{q}$ were not observed in ultra-low carbon steels of which carbon contents are lower than 0.01 mass $\%$. The fraction of $\alpha_{q}$ increases with the cooling rate and the contents of $\mathrm{C}$ and $\mathrm{Mn}$. In $0.001 \% \mathrm{C}$ and $0.002 \% \mathrm{C}$ steels, grain size of ferrite does not decrease 

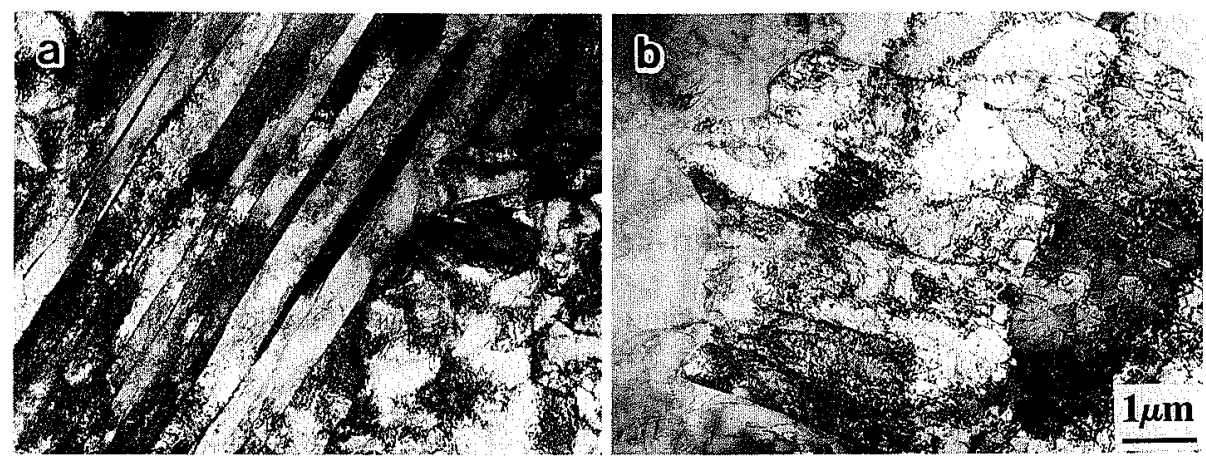

Fig. 23.

Martensite (a) and bainite (b) observed in Steel Bl cooled at $1600^{\circ} \mathrm{C} / \mathrm{s}$ and $640^{\circ} \mathrm{C} / \mathrm{s}$, respectively.

with an increase in cooling rate from $1^{\circ} \mathrm{C} / \mathrm{min}$ to $360^{\circ} \mathrm{C} / \mathrm{s}$. From this fact, it is speculated that the mechanism for the $\gamma \rightarrow \alpha$ transformation is different between 0.001 or $0.002 \% \mathrm{C}$ steels and higher carbon content steels, or that the growth rate of ferrite is very fast comparing with the nucleation rate in such extremely low carbon steels. By boron autoradiography it was known that not a small fraction of grain boundaries of ferrite might be coherent, whereas the relation between $\gamma$ and $\alpha$ grain boundaries could not be elucidated. Dislocation density in $\alpha_{q}$ is higher than that in $\alpha_{p}$ and dislocations tend to form cell structures in $\alpha_{\mathrm{q}}$ matrix. Dislocations, however, which do not form cell structures could be also observed in $\alpha_{q}$ matrix. Precipitation of cementite was observed even in 0.001 and $0.002 \% \mathrm{C}$ steels cooled at $360^{\circ} \mathrm{C} / \mathrm{s}$. For this phenomenon, two explanations can be speculated, whereas further researches are desired. Bainite produced during continuous cooling suppresses discontinuous yielding and $\mathrm{Mn}$ tends to enhance the discontinuous yielding. As the cooling rate increases faster than $360^{\circ} \mathrm{C} / \mathrm{s}$, bainite and martensite become to be observed even in 0.001 and $0.002 \% \mathrm{C}$ steels. During continuous cooling at such higher rate, continuous change from $\alpha_{q}$ to bainite was observed. The moving front of $\alpha_{q}$ produced by rapid cooling is thought to be severely curved at the scale of lath. Martensite can be distinguished from bainite by its higher microhardness and thinner lath width even in extremely low carbon steels such $\mathrm{Fe}-0.002 \% \mathrm{C}$ and $\mathrm{Fe}-1.5 \% \mathrm{Mn}-0.001 \% \mathrm{C}$ steels.

\section{Acknowledgements}

The authors wish to thank Dr. T. Araki for useful discussion, Dr. K. Kunishige, Sumitomo Metal Industries, Ltd., for support of preparing steel and Prof. S.
Harasawa, Institute for Atomic Energy of Rikkyo University, for assists in neutron irradiation. The authors are grateful for experimental assists by undergraduate students Mrs. S. Ohnishi, K. Shimizu and T. Okumura.

\section{REFERENCES}

1) T. Araki, M. Enomoto and K. Shibata: Mater. Trans., JIM, 32 (1991), 729.

2) K. Shibata and K. Asakura: Report Book of Bainite Comm., ISIJ, Tokyo, (1993), 31.

3) S. W. Thompson, D. J. Colvin and G. Krauss: Metall. Trans., 21A (1990), 1493

4) E. A. Wilson: Met. Sci., 18 (1984), 471.

5) D. A. Mirzayev and V. M. Schastlivtsev: Proc. ICOMAT., Jpn. Inst. Met., Sendai, (1986), 282.

6) K. Tsuzaki, K. Fujiwara and T. Maki: Mater. Trans. Jpn. Inst. Met., 32 (1991), 667

7) K. Shibata, N. Kondo, K. Fujita and H. Tanaka: Advances in Cryogenic Engineering Materials, 35, Plenum Press, New York, (1990), 1257.

8) M. Hillert: Metall. Trans., 6A (1975), 5 .

9) E. A. Wilson: ISIJ Int., 34 (1994), 615.

10) T. B. Massalski: Phase Transformation, ASM, Metals Park, Ohio, (1968), 433.

11) B. Jönsson and J. Ågren: Acta Metall. Mater., 38 (1990), 433.

12) T. Maki: Proc. of Int. Forum for Physical Metallurgy of IF Steels, ISIJ, Tokyo, (1994), 183.

13) Z. Nishiyama: Bull. Jpn. Inst. Met., 8 (1969), 325.

14) D. V. Edmonds: Extended abstracts for Int. Symp. on Microstructures of Low Carbon Steels, ISIJ, Tokyo, (1994), 99.

15) T. Araki and K. Shibata: Report No. SW-2-11, Bainite Committee, ISIJ, Tokyo, (1993).

16) T. Maki and K. Tsuzaki: Private communication.

17) D. J. Blickwede: Trans. Am. Soc. Met., 61 (1968), 653.

18) R. P. Smith: Trans. Metall Soc. AIME, 224 (1962), 105.

19) H. Okamoto, M. Oka and N. Sugimoto: Recent Research on Bainitic Microstructures and Transformation Behavior of (Very) Low Carbon HSLA Steels, Bainite Research Comm., ISIJ, Tokyo, (1994), 49. 